\title{
TPACK-RELATED PROGRAMS FOR PRE-SERVICE ENGLISH TEACHERS: AN IN-DEPTH ANALYSIS ON EFFORTS AND ISSUES OF ICT INTEGRATION
}

\author{
I Putu Indra Kusuma \\ Universitas Pendidikan Ganesha, Indonesia \\ Western Michigan University, USA \\ e-mail: indra.kusuma@undiksha.ac.id
}

\begin{abstract}
As the advances of technology bring some changes in education, technology affects teacher training institutions, especially on the integration of Information and Communication Technology (ICT) that supports Technological Pedagogical Content Knowledge (TPACK) programs for English pre-service teachers. Regarding the ICT integration in TPACK-related programs, this study was then conducted to investigate the efforts done by the universities and lecturers and issues faced by the lecturers during the integration processes. This case study was conducted in Indonesia. The participants were 79 lecturers from 25 teacher education institutions implementing TPACK-related programs. This study employed an explanatory sequential mixed-method design in which the data were collected by means of questionnaires consisting of 23 items and interviews containing 5 questions. The results revealed that in general, almost all universities had provided ICT resources, accessibilities, ICT competence development programs, and policies on ICT implementation. On the one hand, for the sake of ICT integration in TPACK related programs, the lecturers provided students with accessibilities, knowledge of ICT, and classroom regulations. However, there are problems faced by those lecturers to integrate ICT in TPACK-related programs. Thus, some possible implications of ICT integration are presented in this study.
\end{abstract}

Keywords: TPACK, ICT integration, ICT integration in ELT, teacher education program.

\section{PROGRAM BERBASIS TPACK UNTUK CALON GURU BAHASA INGGRIS: SEBUAH KAJIAN MENDALAM TERHADAP USAHA DAN PERMASALAHAN INTEGRASI TIK}

\begin{abstract}
Abstrak: Sebagaimana kemajuan teknologi membawa beberapa perubahan dalam pendidikan, teknologi juga mempengaruhi program Lembaga Pendidikan Tenaga Kependidikan (LPTK), khususnya terhadap integrasi Teknologi Informasi dan Komunikasi (TIK) yang mendukung program berbasis Technological Pedagogical Content Knowledge (TPACK) untuk calon guru bahasa Inggris. Terkait dengan integrasi TIK dalam program berbasis TPACK di LPTK, penelitian ini bertujuan untuk meneliti (1) usaha yang telah dilakukan oleh LPTK dan staf pengajar dan (2) permasalahan yang dihadapi oleh staf pengajar selama implementasi program berbasis TPACK. Penelitian ini termasuk dalam penelitian studi kasus survei yang dilaksanakan di Indonesia. Penelitian ini merekrut 79 dosen dari 25 universitas pendidikan yang sedang menjalankan program berbasis TPACK. Penelitian ini menggunakan desain explanatory sequential mixed-method yang mana seluruh data dikumpulkan melalui pengisian kuesioner yang terdiri atas 23 butir dan lima pertanyaan terbuka di panduan wawancara. Hasil penelitian ini mengungkap bahwa secara umum, hampir seluruh universitas telah mengeluarkan usaha seperti menyediakan alat-alat TIK, aksesibilitas, aktivitas pengembangan kompetensi TIK, dan kebijakan implementasi TIK. Di sisi yang lain, usaha yang telah dikeluarkan oleh staf pengajar adalah aksesibilitas, pemenuhan kompetensi TIK, dan aturan di dalam kelas. Namun, staf pengajar menghadapi beberapa kendala selama integrasi TIK. Beberapa implikasi untuk integrasi TIK yang efektif juga disajikan di dalam artikel ini.
\end{abstract}

Kata Kunci: TPACK, integrasi TIK, integrasi TIK dalam pengajaran bahasa Inggris, LPTK.

\section{INTRODUCTION}

Technology has always been a part of English education (Turgut, 2017a) as many Information and Communication Technology (henceforth, ICT) tools have been devised to support the English teaching and learning processes. For instance, laptops, smartphones, and tablets as the current ICT tools have supported 
an increasing interest in mobile pedagogy (Burden, Kearney, Schuck, \& Hall, 2019). Thus, the rapid developments of technology have brought some alterations into English education reforms (Drajati, Tan, Haryati, Rochsantiningsih, \& Zainnuri, 2018; Li, Sun, \& Jee, 2019; Turgut, $2017 b)$. These immense alterations should then be taken into granted by English educators to embrace the new form of learning pedagogy in the current English instructions in the English Language Teaching (henceforth, ELT) context.

Despite the fact that ICT tools have brought some benefits to the English instruction in ELT context (Li et al., 2019), these alterations will inevitably bring uncomfortable situations (Djiwandono, 2019) and many issues as consequences to English educators who are not ready to face them (Drajati et al., 2018) at the same time. Those issues are not limited to the fact that teachers do not know how to implement technology into teaching (Mishra \& Koehler, 2006), fear of change (Koehler \& Mishra, 2009), and the dominations of conventional teaching methods in the digital era (West, 2013). Consequently, the issue of ICT integration into English teaching has received considerable critical attention and has become a relevant topic to discuss in the current ELT context.

Furthermore, Technological Pedagogical Content Knowledge (henceforth, TPACK) is one of the most significant current discussions concerning the issue of ICT integration into ELT. TPACK is a new strategy and paradigm for digital educators to develop efficient technology directions (Koehler \& Mishra, 2009). It is an expanded approach of Pedagogical Content Knowledge (henceforth, PCK) proposed by Shulman in 1986 by adding technological dimension. According to Schulman (1986), PCK refers to the teachers' knowledge of how to teach a subject matter. Years later, Angeli \& Valanides (2005) conducted a study about ICT-related PCK as the addition of the technology dimension to the existing PCK. In the same year, Koehler \& Mishra (2005) also studied this new approach and named it as TPCK but was later renamed as TPACK (Koehler and Mishra, 2008).

Investigating TPACK is a continuing concern within the ELT context in the global era. It is marked by a growing body of studies that have been conducted to investigate the TPACK of English teachers in the $21^{\text {st }}$ century. For instance, Drajati et al. (2018) studied Indonesian teachers' TPACK and reported that Indonesian teachers had good knowledge of teaching with technology as well as knowing some ICT tools that can support the ELT. In addition, Djiwandono (2019) observed Indonesian teachers in terms of their perceptions of ICT integration and revealed that these teachers had good and positive perceptions. However, good knowledge and perceptions will not always result in good implementations. Zyad (2016), in his study, discovered that 56 ELT teachers left the implementation of ICT in the classroom although these teachers argued that they embraced the use of ICT and a student-centered methodology. One plausible answer to this phenomenon is the lack of TPACK development in teacher Education Programs (henceforth, TEPs). As Turgut (2017b) attested this notion, he studied preservice English language teachers' perceived TPACK in sophomore, junior, and senior levels in a TEP and discovered a non-linear pattern of TPACK development of these levels of students even though they had been learning TPACK for years in University. Therefore, more studies to investigate TPACK in-depth are necessary to understand how TPACK can contribute to ICT integration in teaching, especially to support TELL pedagogy.

To date, some researchers have also sought to investigate ICT integration regarding the integration of TPACK in TEPs. Research suggests ICT brings a positive impact on the teachers' practice of teaching (Wong \& Hsu, 2008) from a teacher-centered to a studentcentered approach. ICT implementation has also enhanced the success of ELT practices (Li et al., 2019). Someway, Wong and Hsu argued that this success can only be attained only if the teachers know how to implement the interplay between pedagogical and technological innovations. Thus, the integration of ICT to support TPACK has become a major concern in TEPs and professionalism programs.

The integration of ICT to support TPACK can only be successful if TEPs can create a balanced combination between technology and pedagogy (Zyad, 2016) and collaboration among the stakeholders (Kong, 2019). To create this balanced combination, Hofer \& Grandgenett, (2012) delineated that TPACK can be integrated into TEPs through three aspects, 
such as technology courses, content-specific and teaching methods, course experiences through teacher training programs. Concerning technology courses, Hu and Fyfe (2010) studied that the giving of technology courses has enhanced the self-efficacy of teachers to connect their practice of technology with the content and pedagogy. A year later, Koh \& Divaharan (2011) studied an educational technology course that contained knowledge and experiences of using ICT to students to develop their TPACK. Koh \& Divaharan found that the students could develop their efficacy in using ICT tools to support classroom instructions. Thus, ICT integration through ICT courses which gives knowledge of ICT tools and experiences of using the tools in ELT will enhance the success of TPACK implementation to support TELL.

Apparently, the integration of ICT in teaching is influenced by some factors. If TEPs can acknowledge these factors, the success of ICT integration in teaching can be successfully attained. During a decade, a growing body of research has investigated the affecting factors to the success of ICT integration in teaching (see Buabeng-Andoh, 2012; Hockley, 2014; Jones, 2014; Kong, 2019; Lawrence \& Tar, 2018). Jones (2014) claimed that there are seven affecting factors in the implementation of ICT into lessons. Those factors are confidence during integration, access to resources, time for integration, effective training, knowledge on how to use ICT, personal access during preparation, and age of teachers. On the other hand, Buabeng-Andoh (2012) claimed that ICT integration in teaching is affected by personal characteristics, ICT competence, computer self-efficacy, gender, teaching experience, teacher workload, institutional characteristics, professional development, accessibility, technical support, leadership support, and technological characteristics. Remarkably, Hockley (2014) then proposed different factors that influence ICT integration such as training, student motivation, class size, class time, beliefs, access to resources, culturally appropriate materials, culturally sensitive approaches, and political realities. Later on, Lawrence \& Tar (2018) argued that the factors affecting the integration of ICT involve teacher-level factors (gender, age, educational experience, knowledge of ICT, and attitudes towards ICT), technological factors (the benefits of the technology being used), and institutional factors (supports and resources). Even though they offered different factors, there are some similarities among those factors which can be simplified into teacher's characteristics, supports, knowledge on ICT, and access to resources. These four factors were then used in this study as the underlying dimensions for some data collection instruments.

To date, there are very limited studies that explored the ICT integration in TEPs to support TPACK for pre-service teachers. Martinovic \& Zhang (2012) started the discussion by examining pre-service teachers' perceptions, attitudes, and expectations during their TEPs. As one of the findings was about the challenges, Martinovic \& Zhang discovered that preservice teachers attained insufficient access to ICT and lack of examples of ICT integration in teaching. Lye (2013) then continued the discussion by conducting a study to investigate the opportunities and challenges faced by educational staff during TPACK integration. Lye revealed that the issues faced by the teaching staff were lack of ICT competencies, supports, and instructional design problems. In addition, Voogt \& Mckenney (2017) did a study which aimed at investigating the efforts of five lecturers to develop pre-service teachers' TPACK. Voogt \& Mckenney exposed that the pre-service teachers lack ICT competencies to teach with technology.

With some lacks identified from the aforementioned studies (Martinovic \& Zhang, 2012; Lye, 2013; Voogt \& Mckenney, 2017), it gives more room to some possible investigations. More investigations are needed to understand how pre-service English teachers lack ICT competencies even though they have been provided with TPACK-related programs. Some questions on how universities and lecturers support TPACK development through ICT integration should also be addressed. Moreover, the issues during ICT integration should also be identified to profoundly understand how TPACK related programs contribute to the pre-service teachers' lack of ICT competencies.

Yet, studies that investigates ICT integration conducted by education universities and the lecturers as well as the issues faced during its integration could not be found. Even though the aforementioned studies (Martinovic 
\& Zhang, 2012; Lye, 2013; Voogt \& Mckenney, 2017) have discussed the challenges of ICT integration, those studies did not discuss the efforts done by universities and the lecturers. Also, the aforementioned studies did not discuss the challenges in-depth. It is possible that by understanding the efforts and implementations conducted by the universities and lecturers will give in-depth views to understand some issues related to TPACK development. Thus, more room for improvement to understand the current ICT integration to develop TPACK is necessary. It would be very valuable if a study could give more perspectives viewed from universities and the lecturers as well as indepth explanation on the issues faced during the implementations. It therefore prompted this present study to investigate ICT integration in TPACK-related programs for the pre-service teachers in the 21 st century. More specifically, the aims of this research project have therefore been to investigate (1) the efforts that have been conducted by the universities and lecturers to support TPACK-related programs in terms of ICT integration and (2) the issues faced by the lecturers in supporting TPACK-related programs for pre-service English teachers in terms of ICT integration.

To gain such knowledge, this study was then conducted by recruiting 79 lecturers of 25 English education departments of education universities in Indonesia. Moreover, the data in this study were collected through the implementation of a mixed-methods approach. The present study is hoped to give additional comprehensible literature review of TPACK and ICT integration by the English education universities and the lecturers to support the existence of TELL.

\section{METHODS}

This study belongs to a case study survey research that was implemented in Indonesia. A case study survey research is a research design where a survey is administered to understand a case (Mills, Durepos, \& Wiebe, 2010). The case observed in this study is the efforts that have been conducted by the universities and lecturers to support TPACK-related programs in terms of ICT integration. This was chosen as the case since the latest curriculum in Indonesia required technology integration in all teaching, including in ELT, and the pre-service teachers must have sufficient TPACK to successfully conduct teaching with technology. Thus, the universities and the lecturers were responsible to the fulfilment of the pre-service teachers' TPACK, and how they spent their efforts to support TPACK-related programs in terms of ICT integration was a case that worth of a thorough investigation.

The data collected in the survey is not limited to frequency data, but also other types of data (Christensen, Johnson, \& Turner, 2015). Christensen et al. also explained that a survey can involve questionnaire and interview since both administer questions in data collection, but interview requires an interview protocol. Hence, interview and administering questionnaire differs in methods of data collection. For the purpose of collecting data using both methods in case study survey design, a mixed-methods approach was then implemented. According to Gay, Mills, \& Airasian (2012), mixed methods are a combination of quantitative and qualitative approaches. Regarding the type of mixed methods, this study employed an explanatory sequential mixed methods design. It is a design where the researcher starts to collect the quantitative data as the source of conducting a qualitative inquiry (Creswell \& Creswell, 2018).

The target population of this study was the lecturers who were teaching English at English education departments in Indonesia in preparing pre-service teachers. Invitation along with the consent letter to participate in this study were sent to Facebook and WhatsApp groups of English lecturers. The consent letter explained the benefits as well as the risks and other related information about the study. All lecturers invited were English lecturers who were teaching preservice English teachers at education institutions/ universities in Indonesia, and from 250 lecturers who met with the above purpose, only 80 lecturers from 25 education universities responded to the invitation. Throughout the process, only 79 lecturers participated in this study while one lecturer withdrew the process. Upon the completion of the questionnaire, the researcher approached some lecturers to participate in the interviews to collect more data as an exploration on the issues covered in this study. To be qualified as the participants for interview, the lecturers had to meet some criteria such as (1) a lecturer 
in English education department at an education institution/university, (2) teaching pre-service English teachers, (3) had experiences of teaching with technology or was using technology in their teaching, and (4) had good communication skills in order to collect more profound data. The researcher then approached ten English lecturers who had experiences of teaching English with technology. Among these ten lecturers, five lecturers who met with the above criteria were then selected to participate in the interviews. For the confidentiality purpose of the participants' information, their identities were not displayed in this study.

In collecting the data, this study administered a cross-sectional study survey as the quantitative method while the qualitative method administered interviews. In crosssectional study survey, the participants answered the questionnaire that consisted of 23 items where 2 items were open-ended questions, and the rest 21 items were close-ended questions (Yes and No Questions). All of the questions were about the efforts of universities and lecturers to ICT integration to support TPACK integration. In addition, the questionnaire was developed by involving some dimensions that were gathered from the literature review such as teacher's characteristics, supports, knowledge on ICT, and access to resources. Moreover, these 21 items have been sent for content and construct validations to two experts of educational technology. From the validation process, all items were valid and had less revisions on the construct.

All of the questions were presented as a google form and sent to the respondents. The questions inquired about (1) the efforts had been being done by the universities to support the integration of TPACK in terms of ICT integration; (2) the efforts had been being done by the lecturers to support the integration of TPACK in terms of ICT integration. Meanwhile, the interviews were administered by using an interview guide which consisted of 5 questions inquiring about the problems faced by the lecturers in supporting TPACK integration to preservice teachers in terms of ICT integration. All of the instruments were then validated through an expert judgment process which involved two experts in Educational technology.

All of the data were then analyzed with quantitative and qualitative methods. Both quantitative and qualitative methods were conducted as a triangulation method to ensure the trustworthiness of the data collected in this study. The data derived from the questionnaires were analyzed descriptively by measuring the frequencies and percentage of the responses using SPSS program. The data were then presented in some tables to give a summary of the data findings. Moreover, the data of the interviews were analyzed qualitatively by conducting content analysis technique through doing in vivo coding. The interviews were transcribed into English, and the themes such as (1) the readiness of supporting TPACK-related programs, (2) the efforts to support TPACK-related programs, and (3) the challenges of supporting TPACK-related programs were developed prior to conducting in vivo coding. Then, some possible excerpts were inserted to support the themes presented in this study.

\section{FINDINGS AND DISCUSSION Findings}

The following section presents the findings of the study which involve the quantitative and qualitative data. Table 1 presents the data about the efforts that the universities had been conducting to support TPACK-related programs in terms of ICT integration. The table showed that not all universities provided some courses about ICT that are related to the content of English courses. Only 17 out of 25 universities $(68 \%)$ provided those courses. Moreover, not all universities required their lecturers to use ICT that support the content of English courses where only 19 out of 25 universities (76\%) did. Interestingly, five out of 25 universities (20\%) did not provide the pre-service teachers with free internet access, six out of 25 universities (24\%) did not provide computer/digital laboratories, and one out of 25 universities (4\%) did not provide ICT tools such as laptop, LCD projector, OHP, etc. Surprisingly, not all universities gave full access to the pre-service teachers to use the internet (only 18 out of 25 universities (72\%) allowed free access of using internet) and the computer or digital laboratories provided by the universities (only 16 out of 25 universities (64\%) gave free access to use them). However, almost all universities as marked by 24 out of $25(96 \%)$ gave the pre-service teachers full 
access to use the ICT tools such as laptops, LCD projector, OHP, and other tools. Remarkably, not all universities gave some activities that could develop the students' skills in using ICT tools (only 14 out of 25 universities (56\%) gave these activities) and students' educational technology skills (only 12 out of 25 universities (48\%) gave these activities). Moreover, the open-ended responses that the activities given by 14 universities were workshops, seminars, and courses about common ICT and educational technology applications such as Ms. Applications and LMS platforms.

Additionally, Table 2 shows the lecturers' responses to the efforts that they had done in terms of ICT integration. The findings showed that 75 out of 79 lecturers (94.94\%) gave full access to the pre-service teachers to use laptops/notebooks in the classroom where they were teaching. In addition, 65 out of 79 lecturers $(82.28 \%)$ also gave full access to the pre-service teachers to use other ICT tools such as smartphones/tablets/ internet in the classroom. Surprisingly, only 55 out of 79 lecturers $(69.62 \%)$ joined in some ICT workshops in English language teaching. However, 73 out of 79 lecturers $(92.41 \%)$ showed efforts to search for the updated trends of ICT in ELT, and 75 out of 79 lecturers (94.94\%) learned those materials by themselves. In addition, 75 out of 79 lecturers $(94.94 \%)$ stated that they used ICT tools when teaching. Only 61 out of 79 lecturers $(77.22 \%)$ required the students to use ICT in their classrooms.

Table 1. The Efforts of the Universities in Terms of ICT Integration

\begin{tabular}{|c|c|c|c|c|c|}
\hline \multirow{2}{*}{ No } & \multirow{2}{*}{ Statements } & \multicolumn{2}{|c|}{ Yes } & \multicolumn{2}{|c|}{ No } \\
\hline & & $f$ & fr (\%) & $f$ & $f r(\%)$ \\
\hline 1 & $\begin{array}{l}\text { The university provides some courses about ICT that are related to } \\
\text { the content of English courses. }\end{array}$ & 17 & 68 & 8 & 32 \\
\hline 2 & $\begin{array}{l}\text { The university requires the lecturers to use ICT that support the } \\
\text { content of English courses (e.g., electronic dictionary, websites, } \\
\text { language laboratories, etc. }\end{array}$ & 17 & 68 & 8 & 32 \\
\hline 3 & The university provides a course on educational technology. & 19 & 76 & 6 & 24 \\
\hline 4 & The university provides an internet facility. & 20 & 80 & 5 & 20 \\
\hline 5 & $\begin{array}{l}\text { The university has computer/digital laboratories that can be accessed } \\
\text { by the students. }\end{array}$ & 19 & 76 & 6 & 24 \\
\hline 6 & $\begin{array}{l}\text { The university has ICT tools such as laptops, LCD projector, OHP, } \\
\text { etc. that can be used by the students. }\end{array}$ & 24 & 96 & 1 & 4 \\
\hline 7 & The university provides full access to the students to use the internet. & 18 & 72 & 7 & 28 \\
\hline 8 & $\begin{array}{l}\text { The university provides full access to the students to use the } \\
\text { computer/digital laboratories during college/study time. }\end{array}$ & 16 & 64 & 9 & 36 \\
\hline 9 & $\begin{array}{l}\text { The university provides full access to the students to use the ICT } \\
\text { tools provided. }\end{array}$ & 24 & 96 & 1 & 4 \\
\hline 10 & $\begin{array}{l}\text { The university provides some activities that can develop the students' } \\
\text { skills in using ICT tools (e.g., workshops on creating PPT, Word, } \\
\text { Websites/blogs, applications, etc.) }\end{array}$ & 14 & 56 & 11 & 44 \\
\hline 11 & $\begin{array}{l}\text { The university provides some activities that can develop the students' } \\
\text { educational technology skills (e.g., Workshops on using e-learning } \\
\text { or } L M S \text { platforms, how to use social media for instructions, etc.) }\end{array}$ & 12 & 48 & 13 & 52 \\
\hline
\end{tabular}

Table 2. The Efforts of the Lecturers in Terms of ICT Integration

\begin{tabular}{|c|c|c|c|c|c|}
\hline \multirow{2}{*}{ No } & \multirow{2}{*}{ Statements } & \multicolumn{2}{|c|}{ Yes } & \multicolumn{2}{|c|}{ No } \\
\hline & & $f$ & $f r(\%)$ & $f$ & $f r(\%)$ \\
\hline 1 & $\begin{array}{l}\text { I give full access to the students to use laptops/notebooks in the } \\
\text { classrooms I am teaching at }\end{array}$ & 75 & 94.94 & 4 & 5.06 \\
\hline 2 & $\begin{array}{l}\text { I give full access to the students to use smartphones/tablets/internet } \\
\text { in the classrooms I am teaching at }\end{array}$ & 65 & 82.28 & 14 & 17.72 \\
\hline 3 & $\begin{array}{l}\text { I usually join in some ICT workshops in English language teaching } \\
\text { (ELT) }\end{array}$ & 55 & 69.62 & 24 & 30.38 \\
\hline 4 & I am looking for the updated trends of ICT in ELT & 73 & 92.41 & 6 & 7.59 \\
\hline 5 & I usually learn how to use ICT tools in ELT by myself. & 75 & 94.94 & 4 & 5.06 \\
\hline 6 & I usually use ICT tools when teaching & 75 & 94.94 & 4 & 5.06 \\
\hline 7 & I require the students to use ICT in my classrooms & 61 & 77.22 & 18 & 22.78 \\
\hline
\end{tabular}


Regarding the ICT tools implemented by the lecturers as shown by Table 3, the results from the open-ended question showed that 78 out of 79 lecturers $(98.7 \%)$ implemented Ms. Applications such as Ms. Word, Ms. PPT, and Ms. Excel. In addition, 74 out of 79 lecturers $(93.7 \%)$ used laptops/smartphones/tablets in teaching. Interestingly, only 48 out of 79 lecturers (60.8\%) implemented the learning management system (LMS) and 46 out of 79 lecturers (58.2\%) used ELT websites resources during teaching. Remarkably, only 34 out of 79 lecturers (43\%) implemented Android or IOS applications, 30 out of 79 lecturers (38\%) implemented photo editor applications, and 26 out of 79 (32.9\%) implemented video editor applications in their teaching.

Table 3. ICT Applications Implemented in TEPs

\begin{tabular}{clcc}
\hline No & \multicolumn{1}{c}{ ICT Tools } & $\boldsymbol{f}$ & $\begin{array}{c}\boldsymbol{f r} \\
(\boldsymbol{\%})\end{array}$ \\
\hline 1 & Ms. applications & 78 & 98.7 \\
2 & Laptops/smartphones/tablets & 74 & 93.7 \\
3 & LMS & 48 & 60.8 \\
4 & ELT websites resources & 46 & 58.2 \\
5 & Android and IOS applications & 34 & 43.0 \\
6 & LCD & 74 & 93.7 \\
7 & Social media applications & 70 & 88.6 \\
8 & Photo editor applications & 30 & 38.0 \\
9 & Video editor applications & 26 & 32.9 \\
\hline
\end{tabular}

Based on the above data, an exploratory analysis was conducted through administering interviews to five lecturers. Talking about the integration of TPACK to pre-service teachers in terms of ICT integration, there was an interesting view among the participants that ICT integration in English teaching in Indonesia was not so adequate. They also claimed that this phenomenon was mainly influenced by the lack of ICT competencies of the lecturers in implementing those tools in teaching. As a result, they argued that ICT integration was not so effective and satisfactory enough. Sample excerpts related to this phenomenon are presented as follows:

\section{Excerpt \#1}

"One of the causes that makes implementation of ICT is not successful is all lecturers do not have any sufficient knowledge on ICT, particularly in educational technology such as websites-based teaching, mobile-assisted learning, computer-assisted learning, etc."

\section{Excerpt \#2}

"So far, English education in Indonesia focuses more on PCK rather than focuses on technology and TPACK. Moreover, there are only a few opportunities offered by the universities for the lecturers to join some workshops to deepen our insights of ICT and educational technology".

During the process of the integration of TPACK to pre-service teachers in terms of ICT implementation, the participants confessed that they gave some basic educational technology and ICT courses to enhance the pre-service teachers' understanding and skills to implement ICT in their future teaching. Somehow, the participants did not know in general what kind of ICT they had to encompass in the courses they taught. This was happening because there was no exact agreement nor explanation from the education ministry on what kind of ICT tools that had to be used or needed by the schools. A few examples of quotes are presented below:

\section{Excerpt \#3}

"I mostly teach my students with office applications such as Ms. Words, Ms. PowerPoint, and a few platforms of learning management system. Somehow, I really do not know what ICT tools other than those that I should teach them with. Moreover, there is no much explanation from the education ministry about what kind of technology we should teach or use in our education."

\section{Excerpt \#4}

"The students in my university are taught with some applications that can help them to implement ICT in their future teaching. Yet, the lecturers do not know what particular applications are actually needed in the fields since some schools use different applications and LMS platforms. We are also afraid that the schools where they will be teaching at implementing different applications than what the students have got."

Even though from the questionnaire results above mentioned that the pre-service 
teachers were given full access to use ICT tools during the teaching and learning process, problems were still inherent during the process. Most of the problems were mainly influenced by the low connectivity of the internet as well as low bandwidth provided by the universities as stated by the lecturers. This situation is evident in the quotes provided below:

\section{Excerpt $\# 5$}

"I think most universities in Indonesia now have been providing many sophisticated ICT tools to support the integration of TPACK. However, our common problem during utilizing those tools are limited internet bandwidth. Apparently, most universities cannot provide the faculty members including the students with unlimited bandwidth and high-speed internet. We are still using $3 \mathrm{G}$ speed while other countries are now using 4G LTE."

\section{Excerpt \#6}

"In my university, we have a computer laboratory with more than 30 computers. Yet, the problem is on the internet connection. It is sometimes off and then on all the time. Therefore, some instructions cannot proceed when the connection is off. As a consequence, the implementation of the ICT was not so effective then".

Looking at the readiness of the lecturers to implement ICT in their classes, different views were revealed during the interview. The responses were divided into two such as (1) they were not ready to implement ICT in their classes because they thought that they needed more workshops to join prior to implementing ICT in their classes and need more supports; and (2) they were ready because they had already joined in some trainings about ICT tools. Sample excerpts related to this phenomenon are presented as follows:

\section{Excerpt \#7}

"I think I am not ready yet because I need to know more about ICT tools and their implementation in English teaching. That's why I need to join in some seminars or workshops about ICT usage in ELT. Besides, the supports from the government and the university are not enough to implement TELL, CALL, or
MALL".

\section{Excerpt \#8}

"I think I have got enough knowledge and skills to implement ICT in English language teaching. I learned a lot about educational technology when I studied for my master's degree. Moreover, I also joined in some workshops about ICT integration in classroom practices. Therefore, I am ready to teach my class with technology".

Regarding the readiness of the students in following the integration of ICT, all lecturers confessed that their students were ready to join the class with ICT implementation. But, for some classes or activities that required more advanced ICT tools would create issues during the process. A few examples of quotes are presented below:

\section{Excerpt \#9}

"My students are ready to join in English classes with ICT implementation. Almost all of them know how to use ICT tools. If there are a few of them who don't know how to use the tools, they usually learn from their peers when I assign a group work activity with ICT tools".

\section{Excerpt \#10}

"For some activities that require simple ICT tools to perform such as Ms. Words and PPT, I think my students are ready. But, when I give them activities by using other tools, especially those that are not familiar to them, they will have problems. Unfortunately, they hesitate to ask for guidance".

\section{Discussion}

To address the first research question related to the efforts that have been conducted by the universities and lecturers to support TPACKrelated programs in terms of ICT integration, the findings showed that almost all universities had been spending their efforts in terms of facilities and accessibilities to support the existence of TPACK-related programs. For instance, as found in this study, the pre-service teachers were also provided with various technology tools to support the success of obtaining TPACK during their studies. On the other hand, there were a few of universities which provided the pre-service teachers with no facilities and full 
access to ICT tools. One plausible explanation to this phenomenon is the low resources that might be owned by those universities. As Hockly (2014) explicated, the use of technology is often associated with higher resource contexts which are the characteristics of developed countries. Meanwhile, as a common fact that some Southeast Asian countries, including Indonesia, belong to developing and sub-developed countries. Thereby, it is relatively reasonable that not all universities can provide the same sufficient quality of ICT resources and full accessibilities. As a consequence, it makes the ICT integration to support TPACK-related programs cannot be so satisfactory in a few universities that cannot provide sufficient facilities and accessibilities. These universities should have then realized that to gain the fundamental success of ICT integration in education could be through conducting fundamental efforts such as providing ICT facilities and full access to those ICT tools. As some researchers claimed (see Buabeng-Andoh, 2012; Hockley, 2014; Jones, 2014; Lawrence \& Tar, 2018), among many factors, ICT resources and accessibility are the two fundamental factors that greatly affect the success of ICT integration in education.

The findings in this study also revealed that to support the existence of TPACK-related programs, the universities had provided some courses that involved ICT and educational technology courses. This finding attested to the Polly, Mims, Shepherd, \& Inan's (2010) claim that many ICT courses have been included in the curriculums of teacher education. However, the other findings in this study also found that the attentions of the universities to provide the pre-service teachers with knowledge on how to use ICT through some related activities seem to be below satisfactory levels. Moreover, the activities provided by the universities were only seminars, workshops, and courses about common ICT tools and not about the newly ICT tools in education. Without knowing the latest issues of ICT integration in education through those activities, the pre-service teachers will be left behind by the fast-moving paradigm happening at schools. As a consequence, the preservice teachers might learn again about the ICT tools used at schools from the beginning.

Regarding the data findings, it is assumed that the universities seem to have relatively low attention to the development of the lecturers' ICT competencies since not all lecturers had the opportunities to join in such activities. As a consequence, the lecturers felt that they had a lack of knowledge of educational technology. This finding thereby attested the notion from Mishra \& Koehler (2006) that teachers do not know how to implement technology into teaching because of the lack of ICT competence. These universities should have recognized that the success of TPACK-related programs also depends on the quality of the lecturers in implementing their teaching with technology. Thus, these lecturers need some professional development activities to enhance their knowledge of teaching with technology as few research suggests (Hockley, 2014; Jones, 2014), the effective ICT training to the educators shapes the success of ICT integration. Without any sufficient activities such as seminars and workshops, it is impossible to expect that lecturers can develop their ICT competence.

Even though the attention from the universities were considered relatively low, the findings in this study exposed that the lecturers tried by themselves to update their ICT competencies through looking for some information by themselves or through joining seminars and workshops about ICT. These lecturers also used various ICT tools in their teaching to support TPACK-related programs. These efforts therefore confirm the findings reported by Djiwandono (2019) that educators seem to have a good attitude over ICT integration in education. Moreover, through doing these efforts, the lecturers could still be updated to the latest ICT issues in education and to provide their students with good ICT knowledge. In addition, embracing the students with good ICT knowledge is assumed to have good effects on the future ICT implementation (Thomas, Herring, Redmond, \& Smaldino, 2013). Furthermore, Thomas et al. (2013), contended that the abilities of teachers in implementing ICT are greatly influenced by all knowledge and experiences they received during college years. Thus, the more knowledge and experiences are given to them, the more they will embrace the ICT integration in their future teaching.

To answer the second research question about the issues faced by the lecturers in supporting TPACK-related programs for 
pre-service English teachers in terms of ICT integration, the findings showed that the internet connection, as a classic problem inevitably faced by sub-developed and developing countries, was the essential issue found in this study. Dudeney \& Hockley (2012) argued that wider internet access will expand the opportunity for learners to widen their information access to interesting online resources and more synchronous tools. Thus, it can be assumed that for the universities that still have problems with internet connections may also have problems with enhancing their students' opportunity to expand information access in the process of integrating TPACK. Moreover, Dudeney \& Hockley also claimed that ICT tools will have been fully integrated into the future ELT and will have a direct impact on ELT and materials. Therefore, by having limited access to the internet as well as low connectivity will certainly hinder the opportunity of the pre-service teachers to participate in the fully integrated ICT tools in the future ELT.

Another issue faced by the lecturers found in this study was they did not surely know what kind of ICT they had to teach to the preservice teachers. Even though they argued that they joined in seminars, workshops, and tried to update their ICT knowledge by themselves, they apparently did not have enough insights on ICT tools or applications that were implemented at schools. The plausible explanation for this issue is because the lecturers did not know the current situations of ICT implementations at schools. This finding is in line with the aforementioned one which explained that the pre-service teachers were only given very common ICT seminars, workshops, and courses. This phenomenon can be understood as the lack of ICT knowledge of the lecturers as well as the insights of the current situations of ICT integration at schools. As a result, these lecturers only gave very common ICT knowledge that they were familiar with. As Martinovic \& Zhang (2012) argued, knowing current situations (e.g., the latest software, hardware, and ICT tools at schools) are highly necessary for educators. The lecturers will then be more informed and know what ICT tools they should teach to the pre-service teachers during TPACK-related programs accordingly.

From the aforementioned discussion, some implications can be drawn to TEPs, especially the ones that are related to TPACK-related programs and ICT integration. As discussed in this study, ICT resources and accessibilities are the two fundamental factors that determine the success of ICT integration in Education. Thereby, the aforementioned discussion suggests that English education universities should pay more attention to ICT resources and accessibilities as the major factors for successful ICT integration. Additionally, the good fulfillment of those two factors is necessary to every ICT integration in education. Moreover, deans and educational leaders must play significant and required roles to support the fulfillment of those two factors. Thomas et al. (2013) claimed that the faculty members of the TEPs are the ones that can bring some supports to ICT integration. Thus, the roles of the deans and educational leaders are necessary since the roles of universities and faculty members are vital to the shifts in education. It is hoped that their roles can lead to the implementation of open and integrated TELL approaches. As Rahimi \& Pourshahbaz (2019) explained, these approaches are where the ICT tools are widely implemented to enable the students to have full accessibilities to ICT resources during the teaching and learning process.

Furthermore, English education universities should completely focus on the professionalism programs for the lecturers as well as for the pre-service teachers during their TEPs. Besides providing good ICT resources and accessibilities, the very fundamental actions that can be taken to this issue are the insertion of ICT into curriculum as Thomas et al. (2013) suggested, ICT competence developments as Buabeng-Andoh (2012) as well as Lawrence \& Tar (2018) suggested, and the policies related to ICT integration to support TPACK. By conducting these actions, the success of TPACK integration can be achieved accordingly. In addition, the least issues will be generated during TPACK integration.

Regarding the fact that the current prospective teachers are digital natives (Thompson, 2013), this potential should be taken for granted by the English education universities. By giving more exposures to ICT implementations in ELT, perhaps, they can enhance the chance of ICT integration to support the implementation of TELL/CALL in ELT. As Thomas et al. (2013) argued, the 
abilities of teachers in ICT integration is mostly affected by all knowledge and experiences they received during the college years. Therefore, such experiences about ICT implementations are necessary to be provided by the English education departments and such teacher education-related programs.

\section{CONCLUSION}

The efforts from English education universities as well as from the lecturers to support the integration of ICT in TPACK integration during the TEPS are necessary. As discovered in this study, those efforts conducted by the universities include, but not limited to, providing ICT resources, accessibilities, and activities to develop ICT competence. Moreover, the efforts spent by the lecturers are usually about accessibility, ICT competency fulfillment, and classroom rules. Yet, there are still some issues during ICT integration to support TPACK integration to pre-service teachers during TEPs such as internet connection and the updates of the educational technology tools that the lecturers had to provide their students with. Therefore, it needs critical attention from the universities as well as from the faculty members, especially to ICT resources, accessibilities, and ICT competence fulfillment. Moreover, those issues are greatly influenced by the lack of institutional supports to ICT integration in education.

In addition, there are some limitations discovered in this study. The first limitation addressed in this study is the limited number of lecturers involved in this study. It will be better if future research can involve more lecturers to participate in a similar study. In addition, it is suggested to other researchers to find an effective way to involve more lecturers since it is assumed that the willingness of the Indonesian lecturers to participate in a research study is considerably low. Another limitation addressed in this study is the absence of the students' participation. According to Bordbar (2010), the success of ICT integration depends on the expertise of teachers and the students' part in taking the programs. Hence, it is also important to involve the students in future research to give more colorful findings and discussion to enhance the literature of TPACK integration. The other limitation discovered in this study is the limited factors analyzed in this study. More factors that affect the success of ICT integration in TPACK for pre-service teachers should be conducted in future research.

Hopefully, this study could inspire other researchers to conduct similar studies by involving some factors, variables, and other elements that are missing in this current study. It is also hoped that future research can discuss more issues to enhance the literature of ICT integration to support TPACK for pre-service teachers, especially those that can support the existence of TELL in ELT.

\section{ACKNOWLEDGEMENT}

The acknowledgement in this study is addressed to Western Michigan University that provided free access to articles that support this research, Universitas Pendidikan Ganesha for the support during the process of writing, and English lecturers who had participated willingly contributed precious data to support ICT integration teaching.

\section{REFERENCES}

Angeli, C., \& Valanides, N. (2005). Pre-service elementary teachers as information and communication technology designers: An instructional systems design model based on an expanded view of pedagogical content knowledge. Journal of Computer Assisted Learning, 21(4), 292-302. https://doi.org/10.1111/j.13652729.2005.00135.x.

Bordbar, F. (2010). English teachers' attitudes toward computer-assisted language learning. International Journal of Language Studies, 4(3), 179-206.

Buabeng-Andoh, C. (2012). Factors influencing teachers' adoption and integration of information and communication technology into teaching: A review of the literature. International Journal of Education and Development using Information and Communication Technology, 8(1), 136-155. http://ijedict. dec.uwi.edu//viewarticle.php?id=1361.

Burden, K., Kearney, M., Schuck, S., \& Hall, T. (2019). Investigating the use of innovative mobile pedagogies for schoolaged students: A systematic literature 
review. Computers and Education, 138, 83-100. https://doi.org/10.1016/j. compedu.2019.04.008.

Creswell, J. W., \& Creswell, J. D. (2018). Research design: Qualitative, quantitative, and mixed methods approaches ( $5^{\text {th }}$ ed). Los Angeles, LA: SAGE.

Djiwandono, P. I. (2019). How language teachers perceive information and communication technology. Indonesian Journal of Applied Linguistics, 8(3), 608-616. https://doi. org/10.17509/ijal.v8i3.15260.

Drajati, N. A., Tan, L., Haryati, S., Rochsantiningsih, D., \& Zainnuri, $\mathrm{H}$. (2018). Investigating English language teachers in developing TPACK and multimodal literacy. Indonesian Journal of Applied Linguistics, 7(3), 575-582. https://doi.org/10.17509/ijal.v7i3.9806.

Dudeney, G., \& Hockley, N. (2012). ICT in ELT: how did we get here and where are we going? ELT Journal, 66(4), 533-542. https://doi.org/10.1093/elt/ccs050.

Gay, L. R., Mills, G. E., \& Airasian, P. (2012). Educational research: Competencies for analysis and applications $\left(10^{\text {th }} \mathrm{ed}\right)$. Upper Saddle River, NJ: Pearson Education.

Hockly, N. (2014). Digital technologies in lowresource ELT context. ELT Journal, 68(1), 79-84. https://doi.org/10.1093/elt/cct063.

Hofer, M., \& Grandgenett, N. (2012). TPACK development in teacher education: A longitudinal study of pre-service teachers in a secondary M.A. Ed. program. Journal of Research on Technology in Education, 45(1), 83-106. https://doi.org/10.1080/15 391523.2012.10782598.

Hu, C., \& Fyfe, V. (2010). Impact of a new curriculum on pre-service teachers' technical, pedagogical, and content knowledge (TPACK). In C. H. Steel, M. J. Keppell, P. Gerbic, \& S. Housego. (Eds.). Curriculum, technology and transformation for an unknown future. Sydney: ASCILITE, pp. 185-189.
Jones, A. (2004). A review of the research literature on barriers to the update of ICT by teachers. UK: Becta.

Koehler, M. J., \& Mishra, P. (2005). What happens when teachers design educational technology? The development of technological pedagogical content knowledge. Journal of Educational Computing Research, 32(2), 131-152. https://doi.org/10.2190/0ew7-01wb-bkhlqdyv.

Koehler, M. J., \& Mishra, P. (2008). Introducing TPCK. In AACTE committee on innovation and technology (Ed.). Handbook of technological pedagogical content knowledge (TPCK) for educators. New York, NY: Routledge, pp. 3-29.

Koehler, M. J., \& Mishra, P. (2009). What is technological pedagogical content knowledge? Contemporary Issues in Technology and Teacher Education, 9(1), 60-70. https://citejournal.org/volume-9/ issue-1-09/general/what-is-technologicalpedagogicalcontent-knowledge/.

Koh, J. L., \& Divaharan, H. (2011). Developing pre-service teachers' technology integration expertise through the TPACKdeveloping instructional model. Journal of Educational Computing research, 44(1), 35-58. https://doi.org/10.2190/ec.44.1.c.

Kong, S. C. (2019). Partnership among schools in E-learning implementation: Implications on elements for sustainable development. Educational Technology \& Society, 22(1), 28-43. https://www.jstor. org/stable/26558826.

Lawrence, J., \& Tar, U. (2018). Factors that influence teachers' adoption and integration of ICT in teaching/ learning process. Educational Media International, 55(1), 79-105. https://doi. org/10.1080/09523987.2018.1439712.

Li, G., Sun, Z., \& Jee, Y. (2019). The more technology the better? A comparison of teacher-student interaction in high and low technology use elementary EFL classrooms in China. System, 
84, 24-40. https://doi.org/10.1016/j. system.2019.05.003.

Lye, L. T. (2013). Opportunities and Challenges Faced by Private Higher Education University Using the TPACK Model in Malaysia.Procedia-SocialandBehavioral Sciences, 91(C), 294-305. https://doi. org/10.1016/j.sbspro.2013.08.426.

Martinovic, D., \& Zhang, Z. (2012). Situating ICT in the teacher education program: Overcoming challenges, fulfilling expectations. Teaching and Teacher Education, 28(3), 461-469. https://doi. org/10.1016/j.tate.2011.12.001.

Mills, A. J., Durepos, G., \& Wiebe, E. (2010). Encyclopedia of case study research. Thousand Oaks: SAGE Publications.

Mishra,P., \& Koehler, M. J. (2006). Technological pedagogical content knowledge: A framework for teacher knowledge. Teachers College record, 108(6), 10171054. https://doi.org/10.1111/j.14679620.2006.00684.x.

Polly, D., Mims, C., Shepherd, C. E., \& Inan, F. (2010). Evidence of impact: Transforming teacher education with preparing tomorrow's teachers to teach with technology (PT3) grants. Teaching and Teacher Education: An International Journal of Research and Studies, 26(4), 863-870. $\quad$ https://doi.org/10.1016/j. tate.2009.10.024.

Rahimi, M., \& Pourshahbaz, S. (2019). English as a foreign language teachers' TPACK: Emerging research and opportunities. Hersey, PA: IGI Global.

Shulman, L. S. (1986). Those who understand: Knowledgegrowthinteaching.Educational Researcher, 15(2), 4-14. https://doi. org/10.3102/0013189X015002004.

Thomas, T., Herring, M., Redmond, P., \& Smaldino, S. (2013). Leading change and innovation in teacher preparation: A blueprint for developing TPACK ready teacher candidates. TechTrends, 57(5), 55-63. https://doi.org/10.1007/s11528013-0692-7.

Thompson, P. (2013). The digital natives as learners: Technology use patterns and approaches to learning. Computers \& Education, 65, 12-33. https://doi. org/10.1016/j.compedu.2012.12.022.

Turgut, Y. (2017a). An analysis of TPACK integration into English language TEPs: A comparative study of Turkey and Denmark. Journal on English Language Teaching, 7(4), 1-15. https://doi. org/10.26634/jelt.7.4.13763.

Turgut, Y. (2017b). Tracing pre-service English language teachers' perceived TPACK in sophomore, junior, and senior levels. Cogent Education, 4(1), 1-20. https://doi. org/10.1080/2331186X.2017.1368612.

Voogt, J., \& Mckenney, S. (2017). TPACK in teacher education: Are we preparing teachers to use technology for early literacy? Technology, Pedagogy and Education, 26(1), 69-83. https://doi.org/1 $\underline{0.1080 / 1475939 X .2016 .1174730 .}$.

West, D. M. (2013). Digital schools: How technology can transform education. Washington, DC: Brookings Institution Press.

Wong, Y. K., \& Hsu, C. J. (2008). Online trust in mobile commerce. In P. Cartelli \& M. Palma (Eds.). Encyclopedia of information communication technology. New York, NY: Information Science Reference, pp. 647-655.

Zyad, H. (2016). Pre-service training and ICT implementation in the classroom: ELT teachers' perceptions. International Journal of Education and Development using Information and Communication Technology, 12(3), 4-18. http://ijedict. dec.uwi.edu/viewarticle.php?id=2157. 